\title{
Kroppsdeler, kroppslyder og verdenskulturen
}

\author{
Hvorfor sier vi egentlig prosit når noen nyser?
}

Både i større og mindre forsamlinger er det høyst pinlig hvis en person kommer med uventede lyder. Hoste og kremting går til nød an, men skulle man plutselig finne på å nyse, er det ikke fullt så enkelt. Enda verre er det om det plutselig skulle komme et rap eller en gulp, for ikke å snakke om tarmlyder eller ufrivillig avgang av tarmgass (1, 2).

Aller verst å undertrykke er et nys. Her mobiliseres utrolig sterke muskelkrefter fra omtrent hele overkroppen og hodet, munnen åpnes og øynene lukkes, og så skjer en eksplosjon. Men etterpå føles det desto mer behagelig. Rett etter en større nyseserie er kroppen utrolig avslappet og man kan rett og slett føle lykke. Har noen tenkt på at dette kanskje kunne brukes til å fremme den folkelige lykkefølelsen?

I alle fall er det å nyse et internasjonalt kulturfenomen. Det vil si at nysen innleder til en rekke reaksjoner hos de omkringstående. Disse er kulturelt betinget og varierer fra folkeslag til folkeslag. Foreliggende artikkel er en oversikt over dette viktige fenomenet. Med omfattende språkkunnskaper viser forfatteren hvilken enorm spredning det er på reaksjonsmønstrene i ulike kulturer. Stort sett er responsen positiv, og et fellestrekk er at man ønsker nyseren en god helse. Trolig er det en internasjonal oppfatning at nysing fremmer helse. Forfatteren, Petter S. Hagemo (f. 1943) har studert ved Universitetet i Oslo. Han er spesialist i pediatri med tjeneste fra Bodø og Rikshospitalet i Oslo. Etter å ha arbeidet som overlege på Barnehjerteseksjonen på Rikshospitalet 1986-2010 er han nå pensjonert. Med langvarig praksis fra pediatrien kjenner han barnets naturlige og spontane forhold til kropp og kroppslyder bedre enn de fleste.
Dette fører oss til et vidstrakt emne som har vært altfor lite påaktet hos oss: Hver eneste kroppsdel som kan ses utenfra har sitt eget kulturelle uttrykk, og det varierer både gjennom historien og i ulike land. Tidligere har vi presentert nesens kulturhistorie i denne serien, men det er bare en liten del av et stort fenomen. Avhengig av om et folkeslag bruker den ene eller andre klesdrakten, eventuelt har lite eller ingen ting på seg, vil kroppsdeler være ulikt synlig. Det gjelder kvinnebryst, det gjelder bakenden, og det gjelder penis i ulike reisningsnivåer. For samtlige har det vært skrevet store og lærde monografier om de enkelte kroppsdelenes kulturhistorie (3-5). Det er spennende lesing, for det viser at kultur og kropp er tett koblet sammen. Så kommer kroppsreaksjonene i tillegg, og der inntar nysingen en særstilling.

\section{Ole Didrik Lærum}

ole.laerum@gades.uib.no

Ole Didrik Lærum er professor (adj.) ved Københavns Universitet og professor emeritus ved Universitetet i Bergen.

\section{Litteratur}

1. Wetzel D, Riskin M. The burp book. Watertown, MA: Ivory Tower Publishing Company, 1986

2. Wetzel D, Riskin M. The fart book. Watertown, MA: Ivory Tower Publishing Company, 1983

3. Yalom M. Kvinnebryst. En kulturhistorie. Oslo: Pax Forlag, 1999

4. Hennig J-L. Der Hinteren. Geschichte eines markanten Körperteils. Köln: Vgs Verlag, 1998

5. Vanggaard T. Phallós. København: Gyldendal, 1969

\section{Å nyse - er det fali, det?}

Petter S. Hagemo: A nyse - er det fali, det? Tidsskr Nor Laegeforen 2001: 121: 3629-30

De fleste kroppslyder som produseres, forbigås i taktfull stillhet. Ikke slik med et nys - det er en begivenhet som i svært mange språk og kulturer vil bli kommentert høylytt og hjertelig.

Når en person nyser, stiger det intrakraniale trykk trolig til nivåer som man a priori kan anta medfører risiko for helseskader. Men det er trolig mer obskure forestillinger som ligger bak det faktum at det $\mathrm{i}$ en lang rekke språk finnes tradisjon for å kommentere hendelsen med en hilsen til den nysende person, svært ofte som et ønske om at helsevesenet skal holdes utenfor. Det er erkjennelsen av denne internasjonale hilsningstradisjonen og dennes mulige terapeutiske implikasjoner som har initiert interessen for det nyetablerte fagområdet ptarmolingvistikk (av latin ptarmus = serienys, jf. sternutatio $=$ enkeltnys $)$.

\section{Preliminære}

\section{ptarmolingvistiske studier}

Det religiøse aspekt var tydelig i eldre norsk, der den vanlige hilsen til den nysende var Gud signe eller Krist signe. Dette er tydelig bibeholdt både i engelsk God bless you som brukes både i England og i USA, og faktisk også blant ikke-engelsktalende på Filippinene, og flere andre steder. På Island sier man Guð blessi pig, og i maltesisk, det eneste semittiske nasjonalspråk i Europa, heter det il-Bambin mieghek, som betyr «måtte Jesusbarnet velsigne deg». Tilsvarende har man i arabisk yarhamakom Allah (Allah velsigne deg) og i somalisk alhamdu- lilah (velsigne deg), selv om det her åpenbart er en annen guddom man påkaller.

I Norge, Sverige og Danmark har sekulariseringen tatt overhånd, $\mathrm{og} \mathrm{i}$ våre dager nøyer man seg vanligvis med det livssynsnøytrale prosit, (fra latin «pro esse», konjunktiv «pro sit»= måtte det være til gagn). I Danmark brukes også til dels samme uttrykk som i Tyskland Gesundheit, og det er av interesse å merke seg at Gesundheit også brukes i visse områder uten spesiell tysk dominans i USA, dette er kjent i alle fall i Alabama. I Frankrike sies det à vous souhaits (gode ønsker til Dem).

På spansk sier man ofte kort og godt 
Jesus, mens både i Italia, Portugal og dels også i Spania ønsker man den nysende «helse» ved å si henholdsvis salute, saude og salud. Spansktalende i Colombia kan eventuelt utvide ønsket om helse til salud, dinero, y amor (helse, penger og kjærlighet). I rumensk, som står latin og de andre romanske språk nær, ønskes norok (hell).

I de slavisktalende land Russland, Georgia, Ukraina, Bulgaria hilser man med nazdrovje eller nazdrave som også betyr «til sunnhet». Man merker seg her at akkurat de samme uttrykkene benyttes i betydningen «skål». I albansk, også et slavisk språk, men uten noen nære språklige slektninger, heter det shendet som betyr «helse».

Når vi så forlater den indoeuropeiske språkfamilie og kommer over i den uralske familie og den finsk-ugriske gruppe, finner man en parallell i det ungarske egesegere som også brukes som «skål» og betyr «til helse», mens man i Finland nøyer seg med et høflig spørsmål miten sulla menee (hvordan går det?). I samisk er det ingen tradisjon for noen nysehilsen.

Innen de semittiske språk er det som allerede nevnt vanlig i maltesisk og arabisk å hilse i nevnte situasjon. I hebraisk sier man labriut (til din helse).

Fra andre og mer fjerntliggende språkfamilier kommer for eksempel den tamilske hilsen noorandu i Sør-India og Sri Lanka, som direkte oversatt betyr «100 år» og åpenbart er et ønske om god helse og et langt liv. Som representant for den austroasiatiske familie kan nevnes khmer-språket i Kambodsja, der man sier sbai som betyr «slapp av». I Ghana sier man enkelt og greit $n k w a$ (liv).

Det er kun et fåtall av de hittil ptarmolingvistisk utforskede språk som ikke har noen tradisjonell hilsen. Kuriøst nok er det i denne studien funnet ett i hver av tre språkfamilier, nemlig samisk i den uralske, urdu i den indoeuropeiske og kantonkinesisk i den sinotibetansk-burmanske familie. Det skal dog understrekes at materialet er lite statistisk holdbart grunnet et begrenset antall informanter i hver gruppe $(\mathrm{n}=1)$.

Til slutt en ptarmolingvistisk belysning av det språket som er alle språkhistorikeres uløste gåte, euskara eller baskisk. Sagnet sier at dette er det språket hele verden benyttet før tårnet i Babel raste sammen, så hvis noen har undret seg på hva Eva sa til Adam, eller omvendt, første gang de snuste inn duften av en epleblomst og fikk pollen i nesen, så var det doministicun. Eller kanskje det slett ikke var det, idet dette uttrykket er avledet fra et meget yngre språk, nemlig fra latin «dominis tecum» (Herren være med deg).

\section{Språkhistoriske vurderinger}

Man ser altså at det går to hovedlinjer gjennom ptarmolingvistikken, den ene med ønsker om god helse, den andre om guddommelige makters velsignelse. Flere av informantene har antydet at helseønsket skriver seg fra epidemienes epoke i middel-

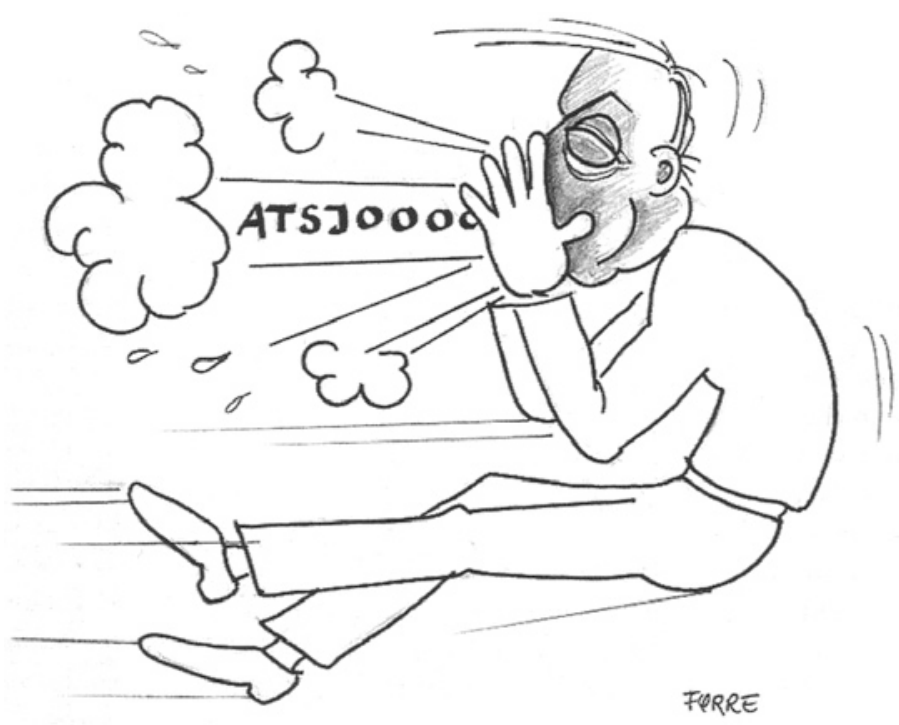

alderen, idet nysing skulle være et tegn på at man var smittet. Det er likevel vanskelig å feste tiltro til denne teorien, da man må anta at hoste skulle være et meget mer alvorlig symptom, og hostehilsen, annet enn «Hold deg for munnen, gutt!» ikke er kjent på samme måte.

\section{Religiøse aspekter}

Viktigheten av de intranasale forhold hos homo sapiens, er påpekt allerede i første bok i historiens mest utbredte litterære verk: «Og Gud Herren dannet mennesket av jordens muld og blåste ånde i hans nese; og mennesket blev til en levende sjel» (1).

Og også annet sted i samme bok finnes tilsvarende: «- for ennu er hele mitt livspust i mig og den A1lmektiges ånde i min nese» (2).

Derimot er ingen av de øvrige kroppsfunksjoner nevnt, verken i de kanoniske eller apokryfe bøker.

Og at et nys har sammenheng med overjordiske makter med mulighet for å påvirke begivenheters gang, er tydelig dokumentert hos Homer i Odysseen (ca. 800 f.Kr.): «- min sønn har nyst til det jeg sa, nå vil det sikkert skje.»

Med den nære relasjon mellom respirasjon og selve livet, er det rimelig å anta at forestillingen om guddommens forbindelse med nys er sentral. Det har vært antydet at et nys innebar at selve guddommen forlot den nysende person og således la veien åpen for demoniske krefter, og en slik invasjon søkte man da å forhindre ved å uttale en religiøs formel.

\section{Vitenskapelige utfordringer}

Tatt i betraktning den sentrale posisjon nys og nysehilsener har, er det høyst påfallende at det ifølge uformelle rundspørringer blant en rekke kolleger fra varierende spesial-

felter, kun var et mindretall som kjente den korrekte latinske termen for fenomenet nys (Hagemo P, upubliserte data), mens de fleste var vel kjent med de latinske beteg- nelser på andre lydfenomener produsert av den menneskelige organisme fra det medisinske studium eller medisinsk klinisk praksis. Således er både tussis, ructus, singultus og flatus familiære begreper.

Det er altså mye som ennå står ugjort på det ptarmolingvistiske området. For å bøte på dette er det nå opprettet en egen forskningsinstans, Norsk Institutt for Ptarmolingvistikk (NIPLI), med hovedarbeidsområde å forske videre på de språklige reaksjoner på nys samt medvirke hertil.

Av de talløse mulige forskningsområder som umiddelbart byr seg kan nevnes: nysetilbøyelighet hos samer sammenliknet med etniske nordmenn bosatt i samme områder, utviklingen av nysehilsener i Kina under kulturrevolusjonen, rhinitthyppighet hos dansker som bruker prosit versus dem som bruker Gesundheit, etc., mulighetene er tallrike. En kartlegging av hvilke uttrykk, om noen, som brukes i de enkelte større og mindre øysamfunn spredt utover det sørlige Stillehav, ville alene være et svimlende forskningsprosjekt om man kunne oppnå reisestipend. Men det haster - språk lever ikke evig, og man må ha det tragiske faktum i tankene at vi aldri vil få vite hva for eksempel etruskerne sa til sine nysende frender.

Kolleger som måtte ønske å vie seg til grundigere studier med tanke på en akademisk karriere innen ptarmolingvistikk, bes ta direkte kontakt med Norges forskningsråd.

De som på mer uforpliktende måte har fakta å bidra med i utforskningen av dette interessante og aktuelle, men akk så forsømte område, bes sende sine bidrag og/eller kommentarer til NIPLI ved instituttbestyreren.

\section{Petter S. Hagemo}

pshagemo@online.no

Norsk Institutt for Ptarrnolingvistikk

Rikshospitalet

0027 Oslo

\section{Litteratur}

1. Bibelen. 1. Mosebok 2, 7.

2. Bibelen. Jobs bok 27,3. 